Universidade Federal do Rio de Janeiro (UFRI)

Faculdade Nacional de Direito Rua Moncorvo Filho, 8

$20211-340$ - Rio de Janeiro - Rio de Janeiro hanna.sonkajarvi@me.com

\section{OSCILANDO ENTRE A ESCRITURAÇÃO MERCANTIL, OS TESTEMUNHOS E A ARBITRAGEM. A CONSTRUÇÃO SOCIAL DAS PROVAS NOS CASOS DE FALÊNCIA NO BRASIL EM MEADOS DO SÉCULO XIX}

\author{
Hanna Helena Sonkajärvi* \\ Universidade Federal do Rio de Janeiro \\ Rio de Janeiro - Rio de Janeiro - Brasil
}

\title{
Resumo
}

O Código de Comércio brasileiro entrou em vigor em 1850, mas a postura dos tribunais nos casos de falência não se modificou radicalmente. O procedimento judicial continuou sendo intensamente condicionado pelos atores locais e pelas ações na fase inicial do processo de falência (conciliação e arbitragem). Nessa situação, determinar o valor das dívidas de negociantes em falência e estabelecer evidências contra essas pessoas para poder provar uma "falência culposa" tornou-se uma tarefa extremamente complicada. Com base em alguns casos de falência na segunda metade do século XIX identificamos fatores que podem explicar porque os tribunais encontraram problemas em estabelecer provas na escrituração mercantil e como eles buscavam, então, chegar a uma decisão.

\section{Palavras-chave}

Falência - peritos - tribunais.

* Doutora em História e Civilização pelo European University Institute de Florença, Itália. Pós-doutora pela Universidad del País Vasco em Leioa (Bilbao), Espanha; pós-doutora pelo Deutsches Historisches Institut/Institut Historique Allemand, Paris; e, ainda, pós-doutora pelo Instituto Universitário de Pesquisas do Rio de Janeiro. Professora adjunta-A de História do Direito no Departamento de Teoria do Direito da Faculdade Nacional de Direito, Universidade Federal do Rio de Janeiro. 


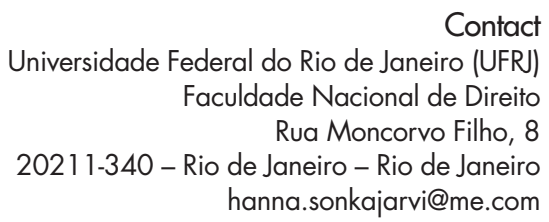

Contact

Universidade Federal do Rio de Janeiro (UFR)

Faculdade Nacional de Direito Rua Moncorvo Filho, 8

2021 1-340 - Rio de Janeiro - Rio de Janeiro hanna.sonkajarvi@me.com

\section{OSCILLATING}

BETWEEN MERCANTILE

BOOKKEEPING,

TESTIMONIES AND

ARBITRAGE. THE SOCIAL

CONSTRUCTION OF

PROOFS IN CASES OF

BANKRUPTCY IN MID-

NINETEENTH CENTURY

BRAZIL

\author{
Hanna Helena Sonkajärvi \\ Universidade Federal do Rio de Janeiro \\ Rio de Janeiro - Rio de Janeiro - Brazil
}

\begin{abstract}
The Brazilian Commercial Code entered in vigour in 1850, but this did not radically alter the manner how bankruptcy cases were handled by the law courts. Legal procedure continued heavily conditioned by local agents and by the actions taken early in the bankruptcy proceedings (conciliation and arbitration). In this situation, the task of determining the value of debt of insolvent merchants and establishing evidence against these individuals to be able to prove the existence of a fraudulent bankruptcy turned extremely complicated. Based on cases of insolvency in the second half of the nineteenth century we will identify factors that might explain why the tribunals struggled to establish evidence in merchants' records and how they would, faced with this situation, try to reach a decision.
\end{abstract}

\title{
Keywords
}

Bankruptcy - experts - law courts. 
Quando Francisco Ferreira de Almeida, ${ }_{1}^{1}$ um comerciante de Porto Alegre, entrou em falência em 1853, os seus livros mercantis foram examinados pelos "juízes arbitrais" junto ao "Juízo Arbitral da Câmara Municipal de Porto Alegre". Esses juízes de arbitragem ${ }^{3}$ foram comerciantes escolhidos pelas partes litigantes que constataram erros graves nos livros de Almeida. Eles suspeitavam que os dados dos livros haviam sido manipulados pelo próprio Almeida ou pelo seu ex-sócio Francisco Antônio Borges. Assim, não foi possível determinar se certas pessoas haviam sido ou não seus credores. Também não ficou claro se os fundos, objeto do conflito entre Almeida e Borges, foram aqueles com que o segundo havia ingressado na sociedade comercial constituída pelos dois, ou se se tratava do montante que Almeida devia a Borges. Em consequência, os livros não serviam de prova e, por saberem como foram administrados os bens da sociedade, as testemunhas foram perguntadas se as partes haviam tido "entre si íntima amizade e ilimitada confiança". ${ }^{4} \mathrm{O}$ processo se alongou e, finalmente, o Juízo Arbitral, não podendo estabelecer um balanço dos negócios do réu em tempo previsto pelo Regulamento 737, encerrou o processo em 5 de junho de 1854, sem pronunciar sentença alguma. ${ }^{5}$

O processo passou então, para a jurisdição do Tribunal Municipal de Porto Alegre. Iniciou-se assim, uma série de processos conduzidos em diversos tri-

\footnotetext{
${ }^{1}$ Francisco Ferreira de Almeida foi comerciante pecuarista e agrícola (notadamente animais, couros, charque, feijão), mas também comercializou têxteis, utensílios de cozinha, ferragem, livros. Ele possuía quota-parte em um navio (Patacho Lívia) e era proprietário de algumas casas e terras em Porto Alegre. Arquivo Nacional (AN). Tribunal da Relação do Rio de Janeiro, 1854. José Francisco de Azevedo Quintão e Francisco Lopes da Costa Moreira, agravantes; Francisco Ferreira de Almeida, agravado, n. 2408, cx. 1605, fl., 652v; 659v-670.

$2 \mathrm{Na}$ forma do art. $411 \S 1^{\circ}$ do Regulamento $n^{\circ} 737$ de 25 de novembro de 1850, que afirmou que o juízo arbitral "[él voluntario, quando é instituido por compromisso das partes". BRASIL. Decreto $n^{\circ} 737$ de 25 de novembro de 1850. Disponível em: <http://www.planalto.gov.br/ CCIVIL_03/decreto/Historicos/DIM/DIM737.htm>. Acesso em: 28/04/2017

${ }^{3} \mathrm{O}$ nosso estudo dos documentos jurídicos e dos artigos de jornais na década de 1850 parece indicar que a noção de "árbitro" se confundia, na prática, com a noção de "juiz de árbitro", mesmo se essas duas noções contivessem um significado distinto na literatura jurídica. No caso de Almeida, participaram seis juízes árbitros. No caso de árbitros terem sido nomeados por juízes como especialistas (peritos) para elaborar parecer sobre a escrituração mercantil, cada uma das partes litigantes poderia normalmente nomear um perito para cumprir a tarefa.

4 AN. Tribunal da Relação do Rio de Janeiro, 1854, n. 2408, cx. 1605, fl. 588v; 594v-595r; 598r; 566r.

5 Para mais detalhes sobre este caso, ver SONKAJÄRVI, Hanna. A aplicação do Código Comercial brasileiro entre 1850 e 1860: análise das evidências de um caso de falência culposa. Tempo. Revista do Departamento de História da UFF, vol. 21, n. 37, Niterói, 2015, p. 170-186. Disponível em: <http://dx.doi.org/10.1590/tem-1980-542x2015v213704>. Acesso em: 29/04/2017.
} 
bunais civis e criminais de primeira e segunda instâncias. Perguntada sobre as práticas comerciais de Almeida, a maioria das testemunhas argumentava "saber por ter ouvido dizer a diferentes pessoas" ou "ter ouvido dizer geralmente". ${ }^{6}$ Assim, põe-se a questão de saber o que constitui, do ponto de vista do tribunal, uma prova jurídica e porque os livros de comércio não serviam de prova.

Apesar do Código de Comércio brasileiro entrar em vigor em 1850 e conter regras para inspeção dos livros do negócio e de toda a escrituração comercial, ele raramente foi seguido à letra e tal inspeção ainda mais raramente serviu de prova para o julgamento de casos de falência. Assim, os tribunais de primeira e de segunda instâncias enfrentaram problemas em determinar se a falência era uma "falência ordinária" ou uma "falência culposa" causada pela negligência ou comportamento criminal do falido e resultando à abertura de um processo na seara criminal. ${ }^{7}$ A partir desta constatação, o objetivo do artigo é discutir, com base em alguns casos ocorridos no Rio de Janeiro e no Rio Grande do Sul, ${ }^{8}$ o porquê de os tribunais terem encontrado problemas em identificar provas nos livros de comércio dos negociantes falidos e como eles buscavam então chegar a uma decisão. Vamos nos ater, assim, a um determinado momento da fase inicial dos processos de falência. Essas fases de conciliação e de arbitragem, que englobavam a verificação dos livros de comércio e de outros documentos mercantis escritos, foram intensamente condicionadas pelos atores locais e acabavam assim influindo em todo o processo de falência na primeira (tribunais municipais) e na segunda instâncias (tribunais de Relação). Enfocando no procedimento judicial relativo ao estabelecimento de provas com base nos livros comerciais, pretendemos investigar como a justiça mercantil se articulou com as ações cotidianas das partes litigantes e dos tribunais - ou seja, como a justiça mercantil foi compreendida e interpretada pelos atores privados e institucionais da época.

\footnotetext{
${ }^{6}$ Entre outras, AN. Tribunal da Relação do Rio de Janeiro, 1854, n. 2408, cx. 1605, fl. 569v; 596r. 7 BORGES, José Ferreira. Diccionario juridico-commercial. Porto: Typ. de Sebastião José Pereira, 1856 [1 ${ }^{\mathrm{a}}$ edição. 1839], p. 161, faz uma divisão entre falência (quebra de "boa fé") e bancarrota ("quebra de má fé"; casos de culpa grave ou de fraude), com referência ao direito comercial francês.

${ }^{8}$ Os casos discutidos aqui fazem parte de documentos do Tribunal da Relação do Rio de Janeiro, conservados no Arquivo Nacional no Rio de Janeiro. O Tribunal da Relação do Rio de Janeiro, conhecido também como "Tribunal da Relação da Corte" foi um tribunal de segunda instância, com competência em um território enorme, indo da província do Rio de Janeiro até o Rio Grande do Sul. O Tribunal da Relação do Rio Grande do Sul e Santa Catarina somente foi criado em 1873 com sede em Porto Alegre.
} 


\section{As falências na legislação brasileira}

O Código de Comércio brasileiro entrou em vigor em 1850 e foi complementado pelo Regulamento n ${ }^{\circ} 737$ de 1850, que normatizou a organização dos tribunais e conferiu uma nova ordem ao processo. Como o Brasil só teve um Código Civil em 1916 (e um Código de Processo Civil em 1939), foram, sobretudo, o Código de Comércio, o Regulamento $\mathrm{n}^{0}$ 737, a Lei de Terras (1850) e a Lei Geral das Hipotecas (1864) que serviram, em parte, como fontes de direito privado. Entretanto, no que tocava ao processo ordinário, o Regulamento seguia, em grande parte, as Ordenações Filipinas (de 1603), as quais também continuaram a ser invocadas em questões não reguladas pelo novo direito, cuja introdução tinha se iniciado com o Código Criminal (1830) e o Código de Processo Criminal (1832). ${ }^{9}$

O Regulamento $n^{0} 737$ determinou que a jurisdição comercial fosse aplicada em todas as causas normatizadas pelo Código de Comércio quando uma das partes fosse comerciante, mas a dívida também tinha de ser comercial. ${ }^{10} \mathrm{O}$ art. 2 do mesmo Regulamento prescrevia que "[c]onstituem legislação comercial o Código de Comércio, e subsidiariamente os usos commerciaes (art. 291) e as leis civis (artigos 121, 291 e 428 do Código). "Os usos commerciaes preferem ás leis civis somente nas questões sociaes (art. 291) e casos expressos no Código".11

Segundo o Regulamento, eram os "Juizes Municipaes, ou do Civel" competentes pelas causas comerciais em primeira instância. ${ }^{12}$ Assim, as controvérsias mercantis eram tratadas na mesma jurisdição dos casos civis, a dos juízes municipais das comarcas. Entretanto, em algumas cidades mais importantes (comarcas especiais) foram criados juízes de comércio que foram considerados juízes especializados. Isso aconteceu no Rio de Janeiro, na Bahia, em São Luís e em Recife, que conheciam assim uma jurisdição comum separada por especialização, para tratar do contencioso mercantil. Além disso, em três províncias, Pará, São Paulo e São Pedro do Sul, se formavam juntas de comércio para administrar e regular atividades mercantis. Em 1851, o Decreto 864 estabeleceu juntas em todas as províncias marítimas. ${ }^{13}$ Os tribunais da

\footnotetext{
9 LOPES, José Reinaldo Lima. O direito na história. Lições introdutórias. 4a edição. São Paulo: Atlas, 2008, p. 271-287.

${ }^{10}$ BRASIL. Decreto $n^{\circ} 737$ de 25 de novembro de 1850, artigos 10 e 11 .

11 Ibidem, art. 2.

12 Ibidem, art. 6.

13 LOPES, José Reinaldo Lima. A formação do direito comercial brasileiro. A criação dos tribunais de Comércio do Império. Cadernos Direito GV, vol. 4, n. 6, São Paulo, 2007, p. 34.
} 
Relação de distritos (Bahia, Rio de Janeiro, Maranhão, Pernambuco) atuavam como segunda instância. ${ }^{14}$ Dessas Relações seria separada uma seção que cuidaria da matéria do comércio (exceto no Maranhão) e essa se chamava Tribunal do Comércio ou Junta. Existia ainda o Supremo Tribunal no Rio de Janeiro, junto ao qual só havia a possibilidade de interposição do recurso de revista (pedido de anulação com base na "nulidade manifesta" ou "injustiça notória" da sentença). José Reinaldo Lima Lopes salienta que "os tribunais de comércio conheciam apenas, como jurisdição originária, das quebras".15 Nota-se que os tribunais de Comércio foram abolidos em 1875 (Lei n 2.662).

A introdução do Código de Comércio em 1850, muitas vezes e sobretudo na literatura jurídica, é percebida como um momento modernizador do sistema judicial brasileiro. ${ }^{16}$ Entretanto, constatam-se várias continuidades entre a ordem anterior a 1850 e após esse ano. Assim, José Reinaldo de Lima Lopes atenta que:

[o] Regulamento [n ${ }^{\circ} 737$ ] de 1850 criou uma cultura e manteve grande parte da cultura antiga. Manteve, por exemplo, os juramentos entre os meios de prova admissíveis em alguns casos e as testemunhas em grande número (podiam ser chamadas até 56 testemunhas, o normal era chamar entre 15 e 20). Elas eram inquiridas por cartas de inquirição, depositavam-se as perguntas em cartório com antecipação. As partes mesmas faziam a "audiência", o termo era lavrado pelo escrivão e os juízes pouco compareciam. Mantivera-se um regime de provas legais (plenas e relativas). Importantíssimo

${ }^{14}$ BRASIL. Decreto n 737 de 25 de novembro de 1850, art. 7: "As relações do districto são Tribunaes de segunda e ultima instancia nas causas commerciaes, e lhes competem: $\S 1^{\circ} \mathrm{O}$ conhecimento por appellação das causas commerciaes cujo valor exceder de 200 mil reis (art. 26 Tit. Unico Codigo). \$ 2. ${ }^{\circ}$ O conhecimento da appellação interposta das sentenças do Tribunal do Commercio nos casos dos arts. 851, 860 e 906 (Codigo)".

${ }^{15}$ LOPES, José Reinaldo Lima. A formação do direito comercial, op. cit., p. 35.

${ }^{16}$ Essa percepção do Código de Comércio como um elemento modernizador coincide com a percepção dos contemporâneos da sua promulgação. Sobre a elaboração do Código, ver BENTIVOGLIO, Júlio. O império das circunstâncias: o Código Comercial e a política econômica brasileira (1840-1860). Tese de doutorado em História Econômica, Universidade de São Paulo, São Paulo, 2002; NEVES, Edson Alvisi. Magistrados e negociantes na Corte do Império do Brasil: O Tribunal do Comércio. Rio de Janeiro: Jurídica do Rio de Janeiro, Faperj, 2008; PAQUETTE, Gabriel. José da Silva Lisboa and the vissitudes of enlightened reform in Brazil, 1798-1824. In: PAQUETTE, Gabriel (org.). Enlightened reform in southern Europe and its Atlantic colonies, c. 1750-1830. Londres: Farnham, 2009, p. 361-388; CARVALHO, Darcy. Desenvolvimento e livre comércio. As ideias econômicas e sociais do visconde de Cairu. Um estudo da história do pensamento econômico brasileiro. São Paulo: Instituto de Pesquisas Econômicas, 1985; KIRSCHENER, Tereza Christina. José da Silva Lisboa, visconde de Cairú: itinerarios de um brasileiro. São Paulo: Alameda, 2009; CHAVES, Cláudia Maria das Graças. Arte dos negócios: saberes, práticas e costumes mercantis no Império luso-brasileiro. America Latina en la Historía Económica, vol. 31, n. 1, México, 2009, p. 171-193. 
na cultura jurídica foi determinar-se que cada ação correspondia a um título diferente (...) (fretamento, seguro, salário), o que resultou no formalismo processual, que já se herdara dos antigos. ${ }^{17}$

Como indica Lima Lopes, o processo foi dominado por escrivães. As partes recolhiam as provas e os testemunhos eram lavrados por escrivães. Eles requeriam aos tribunais contrapagamento para lavrar termos sobre os processos e as decisões já tomadas em outras instâncias. As partes também colhiam testemunhos em audiências que eram conduzidas pelo juiz municipal ou juiz de direito civil do Comércio em presença dos advogados das partes contrárias. Esse tipo de procedimento resultou em uma documentação muito extensa, com muitas repetições. Os processos eram caros e demoravam. Por outro lado, as decisões do Tribunal da Relação muitas vezes não ultrapassavam uma meia página de cada folha dos autos.

As práticas de aplicação do direito mercantil no Império, em nível local e nas diferentes partes do Brasil, ainda constituem um campo mal conhecido. ${ }^{18}$ Mas é possível afirmar que o Código de Comércio de 1850 adotou muitos elementos já existentes na legislação portuguesa e nos costumes dos comerciantes. ${ }^{19}$ Já antes da introdução do Código de Comércio parecem ter

\footnotetext{
${ }^{17}$ LOPES, José Reinaldo Lima. O direito na história, op. cit., p. 287.

${ }^{18}$ Sobre falências de empresas inglesas anteriores à introdução do Código de Comércio, ver KUNIOCHI, Marcia Naomi. Crédito e privilégios de comerciantes estrangeiros no Rio de Janeiro na finalização do tráfico de escravos na década de 1840. História e Economia. Revista interdisciplinar 6, n. 1, 2012, p. 27-50; Sobre o Código de Comércio e o desenvolvimento do sistema bancário e das sociedades anônimas ver GUIMARÃES, Carlos Gabriel. A presença inglesa nas finanças e no comércio no Brasil imperial. Os casos da Sociedade Bancária Mauá, MacGregor \& Cia. (1854-1866) e da firma inglesa Samuel Philips \& Cia. (1808-1840). São Paulo: Alameda, 2012, p. 84-97; LEVY, Maria Bárbara. A indústria do Rio de Janeiro através de suas sociedades anônimas. Rio de Janeiro: Editora UFRJ, Secretaria do Cultura do Rio de Janeiro, 1994, p. 51-57.

${ }^{19}$ Sobre a justiça mercantil e a Lex Mercatoria, ver KESSLER, Amalia D. A revolution in commerce. The Parisian merchant court and the rise of commercial society in eighteenth-century France. New Haven, Londres: Yale University Press, 2007; BASILE, Mary Elizabeth et al. (org.). Lex Mercatoria and legal pluralism: a late thirteenth-century treatise and its afterlife. Cambridge/MA: Ames Foundation, 1998; CORDES, Albrecht. À la recherche d'une Lex Mercatoria au Moyen Age. In: MONNET, Pierre $\mathcal{E}$ OEXLE, Otto G. (org.). Stadt und Recht im Mittelalter. Göttingen: Vandenhoeck \& Ruprecht, 2003, p. 117-132; KADENS, Emily. Order within law, variety within custom: the character of the medieval merchant law. Chicago Journal of International Law, vol. 5, n. 1, Chicago, 2004, p. 39-65. De forma geral, os estudos da história do direito mais recentes representam uma nova maneira de estudar os tribunais comerciais - não como uma organização separada, mas como um ator que faz parte de uma pluralidade de jurisdições. Além do mais, eles sublinham a importância da lei costumeira. Ver, por exemplo, ABÁSOLO, Ezequiel. El código de comercio español de 1829 en los debates y las prácticas jurídicas del extremo sur de América. Anuario de Historia del
} 
existido práticas da justiça mercantil local. Por exemplo, Cláudia Simone de Freitas Munhoz evidenciou que na cidade de Rio Grande já existia uma organização anterior, a "Associação Comercial da cidade do Rio Grande", criada em 1844. Seu regulamento, aprovado pelo presidente da província, conde de Caxias em 1845, não mudou de estatuto depois da introdução do Código de Comércio de 1850. As fontes provam, segundo a autora, que, ainda em junho de 1889, o estatuto continuava sendo o de 1845. Isso demostra a continuidade das práticas já estabelecidas nas praças comerciais. Munhoz afirma que "o Código de Comércio apenas regulou o que já era estabelecido por uso e costume nas praças". ${ }^{20}$ Eugene Ridings, em seu estudo dos empreendedores brasileiros do século XIX, vai além disso e sublinha o papel das autoridades locais na formulação - por meio da prática jurídica - da lei: "The Commercial Code of 1850 provided that usages and customs be determined by the local comercial association, whereupon they became law, duly registered by the comercial courts". ${ }^{21}$ Assim, a tendência dominante na literatura atual de interpretar o Código de Comércio como um fator modernizador mereceria ao menos ser questionada e certamente tem que ser comprovada de uma maneira mais explícita.

Um processo de falência era iniciado com uma tentativa de conciliação. Nessa fase, as partes buscavam chegar a um acordo em um procedimento oral perante o juiz de paz. Esses juízes foram leigos eleitos nas freguesias. ${ }^{22}$ A fase de conciliação foi prescrita na Constituição de 1824. Segundo o artigo 161, nenhum processo jurídico podia ser iniciado sem que anteriormente fosse aplicado o recurso da "reconciliação". ${ }^{23}$ A conciliação não envolvia jul-

Derecho Español, vol. 78-79, n 1, Madri, 2009, p. 447-460; DE RUYSSCHER. Dave. Designing the limits of creditworthiness. Insolvency in Antwerp bankruptcy legislation and practise (16th17th centuries). Tijdschrift voor Rechtsgeschiedenis/Legal History Review, vol. 76, n. 3-4, Leiden, 2008, p. 307-327; PETIT, Carlos. Historia del derecho mercantil. Madri: Marcial Pons, 2016.

${ }^{20}$ MUNHOZ, Cláudia Simone de Freitas. A Associação Comercial do Rio Grande de 1844 a 1852: interesses e atuação representativa do setor mercantil. Dissertação de mestrado, Universidade do Vale do Rio dos Sinos. São Leopoldo, 2003, p. 87.

${ }^{21}$ RIDINGS, Eugene. Business interest groups in nineteenth-century Brazil. Cambridge: Cambridge University Press, 1994, p. 287.

22 BRASIL. Decreto n 737 de 25 de novembro de 1850, art. 24: "Póde intentar-se a conciliação perante qualquer Juiz de Paz, onde o réo fôr encontrado, ainda que não seja a freguezia do seu domicilio". Note-se que, mesmo na fase inicial de conciliação e arbitragem, já havia a participação de "advogados"; sendo que podia se tratar de rábulas como de bacharéis do direito.

${ }^{23}$ CAMPOS, Adriana Pereira \& SOUZA, Alexandre de Oliveira Bazilio de. A conciliação e os meios alternativos de solução de conflitos no Império brasileiro. Dados - Revista de Ciências Sociais, vol. 59, no 1, Rio de Janeiro, p. 273-274. Disponível em: <http://dx.doi.org/10.1590/00115258201677>. Acesso em: 29/04/2017. 
gamento, mas um espaço de tentativa de mediação envolvendo o negociante em falência, seus credores e o juiz de paz. Se não sucedesse a conciliação, o caso seria tratado como de arbitragem voluntária junto ao juízo arbitral da câmara municipal. ${ }^{24}$ Os árbitros eram escolhidos pelas partes litigantes e eram comerciantes, tratando-se, assim, de um julgamento por pares. ${ }^{25}$ Eles examinavam os livros comerciais, os contratos, os escritos de transações e as notas promissórias, quitações e recibos e colhiam testemunhos. Se a arbitragem não resultasse numa sentença, o falido não cumprisse as exigências da sentença ou alguma das partes litigantes tencionasse recorrer da decisão, as partes poderiam recorrer ao juízo de direito da câmara municipal, iniciando-se, assim, um processo judicial conduzido por um juiz ordinário.

Como essas duas fases iniciais de conciliação e de arbitragem não faziam parte de atividade jurisdicional stricto sensu, elas podem ser caracterizadas como infrajustiça, nos termos de Benoît Garnot. ${ }^{26}$ A infrajustiça, segundo ele, seria um modo de resolução de conflitos fora da justiça oficial, mas não necessariamente se opondo a ela. ${ }^{27} \mathrm{~A}$ importância dessas fases de mediação ou litígio informal torna-se evidente se aderimos à visão de Adriana Pereira de Campos e Alexandre de Oliveira Bazilio de Souza, segundo os quais a "grande parte dos processos encerrava-se na própria conciliação". ${ }^{28}$ Esses dois autores constatam, na base de análise quantitativa de algumas freguesias do Rio de Janeiro e de São Paulo entre 1830 e 1899, que a maioria das conciliações se deu por revelia e que a falha da conciliação ocorreu muitas vezes porque o réu não estava presente. ${ }^{29}$

Segundo Amalia Kessler, que foca nos litígios comerciais na cidade de Paris no século XVIII, a vantagem da arbitragem em relação aos litígios comerciais, residia no fato dela não introduzir uma ruptura nas ligações

\footnotetext{
${ }^{24}$ BRASIL. Decreto $n^{\circ} 737$ de 25 de novembro de 1850, art. 441.

${ }^{25}$ Ibidem, art. 189.

${ }^{26}$ GARNOT, Benoît. Justice, infrajustice, parajustice et extrajustice dans la France d'Ancien Régime. Crime, Histoire E Sociétés/Crime, History and Societies, vol. 4, n. 1, Paris, 2000, p. 103-120; GARNOT, Benoît. Histoire de la justice. France, $X V I^{e^{-}} X X^{e}$ siècle. Paris: Gallimard, 2009, p. 354-368.

${ }^{27}$ GARNOT, Benoît. Histoire de la justice, op. cit., p. 697. Entretanto, a noção de infrajustiça tem sido criticada recentemente, pois ela cria uma conotação sugerindo que a justiça de juízes seria a única forma da justiça verdadeira. Ver ARGOUSE, Aude. Prueba, información y papeles. Hacia una plena inclución del escribano y de sus agencias em la historia de la justicia em Hispanoamérica (Chile, siglos XVII-XVIII). Revista Historia y Justicia, vol. 8, Santiago de Chile, 2017, p. 97-137.

${ }^{28}$ CAMPOS, Adriana Pereira \& SOUZA, Alexandre de Oliveira Bazilio de. A conciliação e os meios alternativos, op. cit., p. 288.

${ }^{29}$ Ibidem, p. 288.
} 
interpessoais que formaram a base das relações comerciais. Assim, a qualidade dessas formas de resolução dos conflitos não residia tanto no fato de economizar tempo e dinheiro, mas de permitir a restauração da amizade e da confiança. Ainda segundo Kessler, a arbitragem criou uma situação de pressão social entre os membros do grupo dos comerciantes e credores que facilitava a solução dos conflitos. ${ }^{30}$ Essas observações parecem valer também para o Brasil da segunda metade do século XIX, pois estamos falando de uma sociedade com um sistema bancário ainda precário e não servindo a todo tipo de comerciantes e em todos os lugares, como, por exemplo, os pequenos comerciantes discutidos neste artigo. Apesar de vales bancários circulando pelas províncias nesta época, ${ }^{31}$ esses comerciantes muitas vezes recorriam às práticas de crédito informal ou familiar e necessitavam do crédito de curto prazo para poder investir no cotidiano e comprar novas mercadorias ou matérias primas. Assim se explica uma grande quantidade de transações feitas por meio de notas promissórias que podiam também ser passadas por terceiros como formas de pagamento, como também o grande número de contratos concluídos de forma oral, pois essa oralidade permitia mais flexibilidade entre as pessoas que se conheciam ou estavam interligadas via múltiplas redes de crédito e de negócios. ${ }^{32}$

Os livros comerciais e toda a escrituração mercantil figuravam num lugar proeminente no Código de Comércio e nos regulamentos 737 e 738: O Código estabelecia, logo no início, no capítulo II intitulado “Das obrigações comuns a todos os comerciantes", as práticas que todos os comerciantes deveriam observar (artigos 10-20 do Código de Comércio), sublinhando a importância para todo comerciante de ter livros comerciais bem organizados:

Todos os comerciantes são obrigados: 1 - a seguir uma ordem uniforme de contabilidade e escrituração, e a ter os livros para esse fim necessários; 2 - a fazer registrar no Registro do Comércio todos os documentos, cujo registro for expressamente exigido por este Código, dentro de 15 (quinze) dias úteis da data dos mesmos documentos (artigo $\mathrm{n}^{\circ}$ 31), se maior ou menor prazo se não achar marcado neste Código; 3 - a conservar em boa guarda toda a escrituração, correspondências e mais papéis pertencentes ao giro do seu comércio, enquanto não prescreverem as ações que lhes possam ser relativas (título XVII); 4 - a formar anualmente um balanço geral do seu ativo e passivo, o qual

\footnotetext{
${ }^{30}$ KESSLER, Amalia D. A revolution in commerce, op. cit., p. 70-72.

${ }^{31}$ GUIMARÃES, Carlos Gabriel, op. cit., p. 62.

32 Sobre a economia moral do século XVIII ver FONTAINE, Laurence. Léconomie morale. Pauvreté, crédit et confiance dans l'Europe préindustrielle. Paris: Gallimard, 2008.
} 
deverá compreender todos os bens de raiz móveis e semoventes, mercadorias, dinheiro, papéis de crédito, e outra qualquer espécie de valores, e bem assim todas as dívidas e obrigações passivas; e será datado e assinado pelo comerciante a quem pertencer. ${ }^{33}$

Segundo o art. 11 do Código de Comércio, os comerciantes eram obrigados a ter indispensavelmente o livro diário e o copiador de cartas. O art. 14 determinava que essa escrituração deveria ser feita na "forma mercantil", seguir "ordem cronológica de dia, mês e ano, sem intervalo em branco nem entrelinhas, bordaduras, raspaduras ou emendas". ${ }^{34}$ Além disso, todos os livros deviam ser encadernados e numerados como também selados e rubricados em todas as suas folhas por uma autoridade judicial. ${ }^{35}$ Quanto ao conteúdo:

No Diário é o comerciante obrigado a lançar com individuação e clareza toda as suas operações de comércio, letras e outros quaisquer papéis de crédito que passar, aceitar, afiançar ou endossar, e em geral tudo quanto receber e despender de sua ou alheia conta, seja por que título for, sendo suficiente que as parcelas de despesas domésticas se lancem englobadas na data em que forem extraídas da caixa. Os comerciantes de retalho deverão lançar diariamente no Diário a soma total das suas vendas a dinheiro e, em assento separado, a soma total das vendas fiadas no mesmo dia. No mesmo Diário se lançará também em resumo o balanço geral (artigo $n^{\circ} 10, n^{\circ} 4$ ), devendo aquele conter todas as verbas deste, apresentando cada uma verba a soma total das respectivas parcelas; e será assinado na mesma data do balanço geral. No Copiador o comerciante é obrigado a lançar o registro de todas as cartas missivas que expedir, com as contas, faturas ou instruções que as acompanharem. ${ }^{36}$

Livros que apresentaram vícios não podiam, segundo o art. 15, servir de prova em favor do comerciante. ${ }^{37} \mathrm{~A}$ apresentação total dos livros do comércio podia somente ser exigida pela justiça em casos "de sucessão, comunhão ou sociedade, administração ou gestão mercantil por conta de outrem, e em caso de quebra". ${ }^{38} \mathrm{O}$ comerciante que se recusasse a apresentar a sua escrituração comercial corria risco de prisão. ${ }^{39}$

\footnotetext{
33 BRASIL. Lei no 556, de 25 de junho de 1850, art. 10. Disponível em: <http://linker.lexml.gov.br/ linker/processa?urn=urn:lex:br:federal:lei:1850-06-25;556Eurl=http\%3A\%2F\%2Flegis.senado. gov.br\%2Flegislacao\%2FListaPublicacoes.action\%3Fid\%3D229535\%26tipoDocumento\%3DLEI\%26tipoTexto\%3DPUBEexec $>$. Acesso em: 29/04/2017.

${ }^{34}$ Ibidem, art. 14.

${ }^{35}$ Ibidem, art. 13

${ }^{36}$ Ibidem, art. 12

37 Ibidem, art. 15.

${ }^{38}$ Ibidem, art. 18.

${ }^{39}$ Ibidem, art. 20.
} 
Segundo o Regulamento $\mathrm{n}^{\mathrm{0}}$ 737, em seu art. 138, eram admitidas no Juízo Comercial as seguintes provas:

$\S 1^{\circ}$ As escripturas publicas e instrumentos, que são como taes considerados pelo Código Commercial e leis civis. $\S 2$ Os escriptos particulares. $\S 3^{\circ}$ A confissão judicial. $\S 4^{\circ} \mathrm{A}$ confissão extrajudicial. $\S 5^{\circ} \mathrm{O}$ juramento suppletorio. $\S 6^{\circ} \mathrm{O}$ juramento in litem. $\S 7^{\circ}$ As testemunhas. $\S 8^{\circ}$ As presumpções. $\S 9^{\circ} \mathrm{O}$ arbitramento. $\S 10 \mathrm{O}$ depoimento da parte. $\S 11$ As vistorias. ${ }^{40}$

O uso de testemunhas estava explicitamente previsto para os casos de falência, no artigo 818 do Código de Comércio. Este estatuou que testemunhas podiam ser ouvidas para estabelecer as causas de falência no início do processo:

Fechado o balanço, ou ainda mesmo pendente a sua organização, procederá o Juiz comissário, conjuntamente com o Curador fiscal, ao exame e averiguação dos livros do falido, para conhecer se estão em forma legal (art. 13), e escriturados com regularidade e sem vício (art. 14). Indagará outrossim a causa ou causas verdadeiras da falência, podendo para este fim perguntar as testemunhas que julgar precisas e sabedoras, as quais serão interrogadas na presença do falido ou seu procurador, e do Curador fiscal; a cada um dos quais é lícito contestá-las no mesmo ato, e bem assim requerer qualquer diligência que possa servir para descobrir-se a verdade; ficando todavia ao arbítrio do Juiz recusar a diligência quando lhe pareça ociosa ou impertinente. ${ }^{41}$

Na hierarquia das provas, o Regulamento 737 estabelecia, nos artigos 140 e 141, uma diferenciação entre "provas plenas absolutas" e "provas plenas relativas". Segundo o art. 140, constituíam prova plena absoluta:

$\S 1^{\circ}$ As escripturas, instrumentos publicos, e os actos que são como taes considerados pelo Codigo (arts. 21, 52, 569, 587 e 633) e pelas leis civis. $\$ 2^{\circ}$ Os actos authenticos passados em paizes estrangeiros, conforme ás leis respectivas, competentemente legalizados pelos Consules brazileiros. ${ }^{42}$

O artigo 141 estabeleceu que os livros comerciais constituíam as chamadas "provas plenas relativas". Faziam parte deste tipo de provas:

$\S 1^{\circ}$ Os instrumentos particulares dos contratos commerciaes entre as partes que os assignarem. $\S 2^{\circ}$ Os escriptos de transacções commerciaes de qualquer valor contra o

\footnotetext{
${ }^{40}$ BRASIL. Decreto ${ }^{\circ} 737$ de 25 de novembro de 1850, art. 138.

${ }^{41}$ BRASIL. Lei ${ }^{\circ} 556$, de 25 de junho de 1850, art. 818.

${ }^{42}$ BRASIL. Decreto $n^{\circ} 737$ de 25 de novembro de 1850, art. 140.
} 
commerciante que os assignar (artigos 22 e 426 do Codigo). $\S 3^{\circ}$ Os livros commerciaes, nos casos e pela fórma regulada nos arts. 20, 23, 3544 do Codigo). ${ }^{43}$

Segundo o art. 144, a "prova plena relativa" podia ser contestado pelas testemunhas orais:

A presumpção que a prova plena relativa induz é restricta ás partes contratantes e seus herdeiros, e comprehende não só a existencia do contrato, e dos actos e factos certificados no instrumento pelo Official publico, por se haverem passado na presença delle e das testemunhas, mas tambem os actos e factos referidos, narrados ou enunciados, si elles têm relação directa com o contrato. Em todo caso os actos e factos referidos, narrados ou enunciados fazem prova plena contra aquelle que os refere, narra ou enuncia. ${ }^{44}$

A diferença feita entre as "provas plenas absolutas" e "provas plenas relativas" parece seguir a mesma linha da antiga legislação portuguesa, e baseada nos direitos romano e canônico, entre as "provas plenas" e "provas semiplenas". Segundo António Manuel Hespanha, "semiplena" era uma prova que não era suficiente em si mesma, mas que teria que ser conjugada com outras evidências. ${ }^{45}$ Ainda nessa lógica das provas, não era necessário provar "o que fosse notório ou o que fosse inevitavelmente incerto". ${ }^{46}$

Amalia Kessler destaca que essa distinção, na visão de alguns juristas franceses dos séculos XVII e XVIII, traz problemas em relação aos livros do comércio. Pois, mesmo se a escrituração mercantil não foi pública no sentido de ter sido oficializada no cartório, ela foi algo que foi mantida pelo próprio comerciante, para proveito de todas as pessoas que estavam querendo fazer transações com o mesmo. Nesse sentido a escrituração foi direcionada pelo público e servia à comunidade mercantil. Por esse motivo, alguns autores (Kessler se refere a Jean Toubeau (1628?-1685) e Joseph-Nicolas Guyot (17281816) $)^{47}$ consideravam que os livros de comércio constituíam uma categoria

\footnotetext{
43 Ibidem, art. 141.

${ }^{44}$ Ibidem, art. 144. As testemunhas foram admitidas em juízo comercial nos contratos cujo valor não excedia a quatrocentos mil-réis. BRASIL. Lei $\mathrm{n}^{0}$ 556, de 25 de junho de 1850, art. 123, definia que "Em transações de maior quantia, a prova testemunhal somente será admitida como subsidiária de outras provas por escrito".

${ }^{45}$ HESPANHA, António Manuel. Como os juristas viam o mundo, 1550-1750. Direitos, estados, pessoas, coisas, contratos, ações e crimes. Lisboa: s. e., 2015, p. 586-587.

${ }^{46}$ Ibidem, p. 586-587.

${ }^{47}$ Cf. TOUBEAU, Jean. Les institutes du droit consulaire, ou la jurisprudence des marchands. Paris: J. Guignard, 1682; GUYOT, Joseph-Nicolas. Répertoire universel et raisonné de jurisprudence civile, criminelle, canonique et bénéficiale, ouvrage de plusieurs jurisconsultes, 17 volumes. Paris: Visse, 1784-1785.
} 
intermediária entre público e privado e, em consequência, a qualificação deles como provas plenas ou semiplenas complicou-se nessa perspectiva. ${ }^{48}$

A secção VII do Regulamento 737 estabeleceu as regras da arbitragem. Já o Regulamento 738 de 25 de novembro de 1850 continha regras específicas para casos de falência, por ser tratado nos tribunais de Comércio, ${ }^{49}$ sendo que as falências de comerciantes matriculados formaram competência dos tribunais do Comércio e que, em relação às falências de comerciantes não matriculados, competia o conhecimento da quebra aos juízes municipais que, segundo o artigo 184, "exercerão cumulativamente as funcções dos Juizes Commissarios e as dos Tribunaes do Commercio". ${ }^{0}$ A obtenção da matrícula na Junta do Comércio no Rio de Janeiro foi obrigatória a partir de 1809 somente para os negociantes de grosso trato (venda por atacado). ${ }^{51} \mathrm{Em}$ consequência, um número significante de casos de falência parece de fato ter sido tratado pelos juízes municipais à vez de entrar na órbita de tribunais de Comércio especializados. Na prática, quando se tratava de comerciantes pequenos, determinar quem era negociante e, por consequência, submetido à jurisdição mercantil, podia causar dificuldades.

\section{As dificuldades no exame da escrituração mercantil}

Mas qual foi, além da legislação, o significado do exame dos livros mercantis nos casos de falência? Problemas similares ao já referido caso de Ferreira Almeida surgiram em outro caso de falência, o de A. S. Levy, comerciante de joias e judeu da Alsácia que, em 1858, por ter incorrido em falência culposa em Pelotas, no Rio Grande do Sul, fugiu da cidade. Nesse caso, o Tribunal da Relação de segunda instância enfrentou grandes dificuldades para determinar se Levy estivera, na verdade, em uma sociedade comercial ou se ele havia agido sozinho. ${ }^{52}$ Esse problema acompanhou todo o processo

\footnotetext{
48 KESSLER, Amalia D. A revolution in commerce, op. cit., p. 88.

${ }^{49}$ Brasil. Decreto $n^{\circ} 738$ de 25 de novembro de 1850. Disponível em: <http://www.planalto.gov. br/ccivil_03/decreto/Historicos/DIM/DIM738.htm>. Acesso em: 29/04/2017.

50 Ibidem, art. 184.

${ }^{51}$ FRAGOSO, João Luís Ribeiro. Homens de grossa aventura: acumulação e hierarquia na praça mercantil do Rio de Janeiro (1790-1830). Rio de Janeiro: Arquivo Nacional, 1992, p. 34, define os comerciantes de grosso trato como "negociantes, em geral, envolvidos simultaneamente no tráfico internacional de escravos, no abastecimento interno e nas finanças coloniais".

${ }^{52}$ AN. Tribunal da Relação do Rio de Janeiro, 1859. Juiz de Distrito da 1a Vara Crime do Corte do Rio de Janeiro. Carlos Constant Chatenay e Randolpho Fischer, administradores da massa falida de A. S. Levy, apelantes, Santiago de Prate e M. J. Schlosmann, apelados, nº 837, maço 163. Em
} 
de falência, inclusive os processos anexos iniciados pelos diferentes credores, desde a arbitragem local até o Tribunal de Relação no Rio de Janeiro. Como Levy tinha fugido da cidade, nesse caso, não se recorreu à conciliação, embora o irmão dele, negociante no Rio de Janeiro, tenha feito tentativas nessa direção. Em $1^{\circ}$ de março de 1859, o juiz de direito da Primeira Vara do Comércio, doutor João Baptista Gonçalves Campos, mandou os peritos Manuel Joaquim de Oliveira Junior e Antônio Victor de Assis Silveira investigar os livros mercantis de Levy, com base nas dez questões formuladas nas linhas definidas pelo próprio Código de Comércio:

Quezitos para os exames dos livros dos falidos. $=$ Quaes são os livros que o falido tem, e se são os necessários ao seu Commercio e se as respectivas escrituração [sic] esta mercantilmente feita, em harmonia com todas as transacções, e até que datas = primeiro. $=$ Se os Livros Diarios, e Copiador estão selados, numerados, e rubricados de conformidade com o artigo treze do Codigo $=$ segundo. $=$ Se a escripturação do Diario esta feita com individuação, e clareza compreendendo todas as operações commerciaes do falido, quer de sua, quer de alheia conta, como determina o artigo doze do Codigo, e se segundo, digo, e se he seguida chronologicamente, sem intervalas em branco, nem entrelinhada, borraduras, raspaduras, ou emendas $=$ terceiro. $=$ Se existem vendas por menos do preço corrente, de efeitos que o falido houvesse comprado nos seis meses anteriores a quebra, e se acha assi que devendo $=$ quarto. $=$ Se existe $\mathrm{o}$ balanço anual do activo, e passivo das obrigações commerciaes do falido, compreendendo todas as espécies de valores determinados pelo paragrapho quarto do artigo dez do Codigo, se os algoritmos desse balanço confirmam a importância dos saldos das contas individuaes constantes do Livro Razão do mesmo Diario, se neste esta lançado em rezumo o dito Balanço, e se este esta assignado pelo falido $=$ quinto. $=$ Se o falido entre a data do seu ultimo balanço e a da falencia se acha devendo por obrigação direitos o dobro do seu cabedal apurado nesse balanço $=$ sexto. $=$ Qual a importância do fundo capital do falido, e de que espécies; se compõem esta importância = sétimo. $=$ Que a importância ao debito, e de credito da conta particular do falido de que espécies se compõem, e que o saldo relativo aos dois últimos anos a data da abertura da falência $=$ oitavo. $=$ Qual a importância das despesas gerais, e do negocio do falido nos dois últimos anos até o dia da abertura da falência $=$ nono. $=$ Qual a importância do debito, e do credito da

ambos os casos, no caso de Almeida e de Levy, tratava-se de comerciantes não matriculados pela Junta Comercial, e os tribunais tinham que confiar no depoimento das testemunhas para buscar resolver os casos. 
conta de ganhos e perdas e se todos os artigos dessa conta tem huma origem conhecida, e verdadeira $=$ decimo $^{.53}$

O resultado do exame foi que o diário, o livro de contas e o livro de caixa do falido apresentavam graves lacunas, não permitindo precisar qual a importância do volume de negócios ou quais os credores ou devedores e os montantes devidos. Também não existia uma balança comercial. Os peritos constataram assim que:

A escripturação não esta mercantilmente feita, por isso que lhe faltão as contas geraes indispensáveis para poder-se entrar na apreciação de sua harmonia. (...) Que não he possível chegar-se a conhecer se o falido omitio lançamento de transações de sua, ou de alheia conta, porquanto faltando as contas geraes, onde se poderia estudar esta resposta faltão todos os dados aos peritos. ${ }^{54}$

O que ambos os casos - de Almeida e de Levy - evidenciam é que a leitura dos livros resultou sendo extremamente difícil, mesmo tendo o Código de Comércio estabelecido regras detalhadas sobre a escrituração mercantil. Por exemplo, ter-se-ia de decidir se se poderia ou não conferir significado às mudanças na cor ou na densidade da tinta e nas palavras corrigidas ou acrescidas em momentos posteriores. Como no caso de Francisco Ferreira de Almeida, também no caso de A. S. Levy surgiram, posteriormente à falência, credores suspeitos de já terem sido pagos antes da falência, tendo em vista o aumento da soma devida por Levy depois da fuga do mesmo.

Tudo isso foi possível porque os comerciantes de preferência agiam com base nos contratos feitos em comunicação oral e porque não existia uma obrigação de oficializar as transações no cartório. Assim, os administradores da massa falida de Levy se recusaram a admitir o negociante Ignácio Ribeiro Chaves como credor. Ele reclamou de ter dado a Levy um crédito de doze contos de reis, mas os livros de Levy só falavam de dois contos de reis. No curso desse processo, foi constatado que "o livro 'diário' apresentado pertence ao autor Ignácio Ribeiro Chaves, não se acha sellado nem rubricado, porém escripturado mercantil, e chronologicamente, e a escripturação limpa; sem emenda, entrelinha, ou cousa que duvida faça" ${ }^{55}$ Entretanto, a partir

\footnotetext{
${ }_{53}$ Ibidem, fl. $138 \mathrm{v}-139 \mathrm{v}$.

${ }^{54}$ Ibidem, fl. 137v-138r.

55 N. Supremo Tribunal da Justiça, 1858-1859. Apelação em grau de revista em que é suplicante Ignácio Ribeiro Chaves e apelados administradores da massa falida de A. S. Levy, nº 458, cx. 1528 , sin fl.
} 
dessa verificação, o conteúdo não foi posto em questão. Chaves venceu o processo no Tribunal da Relação e o Supremo Tribunal rejeitou o recurso.

Outro caso de falência, tratado no Tribunal da Relação do Rio de Janeiro em 1861-1862, torna a fragilidade de escrituração mercantil como prova ainda mais visível. Os apelantes, Manuel Fernandes d'Oliveira e Antônio Caetano Pereira Maciel, tinham sido condenados em falência pelo Juízo Especial do Comércio da Segunda Vara do Rio de Janeiro em junho de 1861. Eles foram subsequentemente julgados em janeiro de 1852 para cumprir uma pena de quatro anos e meio de prisão simples, por juiz de direito da Primeira Vara Criminal do Rio de Janeiro. O juiz criminal fundamentou a sentença dizendo que:

procedem porem as arguições de não se haverem apresentado em Juizo pedindo a abertura da falencia na forma da lei, e de não terem os livros na forma da lei, pelo artigo 13 do mesmo Codigo [Comercial] (...). E assim julgando os réos, falidos culposos em vista do disposto nos $\S \S 1^{\circ}$ e $2^{\circ}$ do Artigo 801 do dito Codigo, e tendo atenção à não concorrerem circunstancias agravantes ou atenuantes, os condemno, cada hum como incurso no gráo médio do Artigo 263 do Codigo Criminal, combinado com o 821 do Comercial, à quatro anos e meio de prisão simples, pagas as custas pela massa falida. ${ }^{56}$

No seu pedido de revisão em segunda instância, o advogado dos apelantes argumentava que os livros de comércio não podiam servir como a única prova para estabelecer uma "falência culposa". Ele se baseou notavelmente nos autores franceses Jean-Marie Pardessus, ${ }^{57}$ autoridade frequentemente citada pelos advogados em relação ao direito comercial no Brasil, o penalista Faustin Hélie ${ }^{58}$ e o especialista do direito administrativo e processual Adolphe Chauveau. ${ }^{59}$ Em seguida, no dia 8 de abril de 1862, o Tribunal da Relação do Rio de Janeiro absolveu os acusados:

\footnotetext{
${ }^{56}$ AN. Tribunal da Relação do Rio de Janeiro, 1861-1862. Antônio Caetano Pereira Maciel e Manuel Fernandes d'Oliveira, apelantes e a Justiça, apelado, no 808, cx. 146, fl. 142v-143r.

57 Jean-Marie Pardessus publicou, entre outras obras, PARDESSUS, Jean-Marie. Élémens de jurisprudence commerciale. Paris: Durand, 1811; Idem. Cours de droit comercial. 4 volumes. Paris: Librairie Garnery, 1814-1816. Sobre Pardessus, ver HILAIRE, Jean. Pratique et doctrine au début du XIXe siècle. L'oeuvre de Jean-Marie Pardessus (1772-1853). In: DEPERCHIN, Annie; DERASSE, Nicolas; DUBOIS, Bruno (org.). Figures de justice. Études en l'honneur de Jean-Pierre Royer. Lille: Centre d'Histoire Judiciare, 2004, p. 287-294

${ }^{58}$ Notavelmente autor de HELIE, Faustin. Traité de l'instruction criminelle ou théorie du Code d'instruction criminelle. 9 volumes. Paris: C. Ingray, 1845-1860.

${ }^{59}$ Notavelmente autor de CHAUVEAU, Adolphe. Manuel de la contrainte par corps en matière civile et commerciale. Paris: Veuve C. Béchet, 1829; Idem. Formulaire général et complet, ou Traité pratique de
} 
não havendo, como se vê de autos de parte dos acusados dolo, a má fé, p[e]lo contrario são abonados p[e]los seos mesmos credores, e p[e]las testemunhas, q[ue] affirmão serem pontuais, e sempre zelosos no cumprimento dos seos deveres, sendo devido antes esse seo transtorno á falta de pagamento dos seos credores p[e]lo $2^{\circ}$ ponto t[am]bem não procede a falta porq[u]e sendo como hé de pouca importância o seo comercio, não havendo má fé, e fraude, o q[ue] constitue o crime, e facultativa a imposição da pena do art. 821 do Codigo Comercial, não pode ter lugar neste cazo a pena comercial. ${ }^{60}$

O Tribunal da Relação reconheceu assim os testemunhos dos credores que falavam em favor de dois apelantes, condenados de falência culposa na primeira instância, como também constatou que o volume do comércio deles foi pequeno, o que implicaria, na visão do tribunal, que eles não podiam ser condenados com todo rigor em relação ao art. 821 do Código Comercial que previa uma pena de prisão de oito anos para quem cometesse falência culposa. ${ }^{61}$

\section{As práticas sociais na determinação das provas}

De fato, os casos estudados aqui permitem confirmar que o procedimento dos tribunais, nos casos de falência, foi completamente baseado na comunicação escrita, mas, ao mesmo tempo, o grau de confiança que os tribunais tinham em relação à palavra escrita parece ter sido muito baixo. A desconfiança torna-se expressa sobretudo em relação aos livros mercantis e outros comprovantes de transações, pois eles parecem ter sido menos valorizados como provas do que as testemunhas, que também acessavam os tribunais por via da palavra escrita.

Como explicar essa discrepância entre o tratamento das palavras escritas dos comerciantes e das palavras dos comerciantes escritas pelos escrivães? Com base em poucos casos estudados e apresentados aqui, podemos formular algumas hipóteses provisórias.

Um primeiro aspecto que poderia explicar essa discrepância está relacionado com a atuação dos peritos como especialistas na verificação da escrituração mercantil. Assim, a verificação dos livros mercantis foi realizada pelos pares. Comerciantes indicados pelas partes litigantes atuavam como

\footnotetext{
procédure civile et commerciale, revu par M. Glandaz. 2 volumes. Paris: Imprimérie de Cosse, 1852.

${ }^{60}$ AN. Tribunal da Relação do Rio de Janeiro, 1861-1862. Antônio Caetano Pereira Maciel e Manuel Fernandes d'Oliveira, apelantes e a Justiça, apelado, no 808, cx. 146, fl. 170r.

${ }^{61}$ BRASIL. Lei n ${ }^{0}$ 556, de 25 de junho de 1850, art. 821: "Em quanto no Código criminal outra pena se não determinar para a falência com culpa, será esta punida com prisão de um a oito anos".
} 
especialistas no processo judicial com o objetivo de oferecer uma visão sobre os aspectos técnicos de escrituração inspecionados por eles. De fato, esses peritos atuavam como um tipo de brokers entre os litigantes, tendo que negociar os interesses de diferentes credores em relação ao comerciante ou negócio falido. ${ }^{62}$ Assim sendo, a figura do perito, típico para a justiça mercantil, nada teve a ver com a separação entre os papéis públicos e privados dos atores envolvidos no processo judicial - algo que, segundo Niklas Luhmann, permitiria ao processo judicial moderno, como um sistema social, ganhar legitimidade por meio da "autonomia relativa" do sistema jurídico. ${ }^{63}$ Pelo contrário, os árbitros estavam completamente inseridos na própria paisagem microeconômica em que eles teriam que explicar e julgar ${ }^{64}$ a atuação de pessoas que eles podiam perceber como parceiros (passados, atuais ou potenciais) ou como rivais. A arbitragem inicial esteve condicionada pelo fato de que os juízes arbitrais eram, em verdade, comerciantes e detinham, muitas vezes, cargos governamentais, como vereadores da câmara municipal, juízes de paz e deputados provinciais em nível local e provincial. ${ }^{65} \mathrm{O}$ juiz arbitral

\footnotetext{
${ }^{62}$ CALAFAT, Guillaume. Expertise et compétences. Procédures, contextes et situations de légitimation. Introduction à l'atelier doctoral "Expertise et compétences". Hypothèses, vol. 14, n. 1, Paris, 2010, p. 103.

${ }^{63}$ LUHMANN, Niklas. Legitimation durch Verfahren. $3^{a}$ edição. Frankfurt am Main: Suhrkamp, 1983 [1. ed. 1969], p. 69-74. Numa ótica pré-moderna, CERUTTI, Simona. Giustizia sommaria: Pratiche e ideali di giustizia in una società di Ancien Régime (Torino, XVIII secolo). Turim: Feltrinelli, 2003, p. 12, defende a ideia de que o procedimento era o elemento central do processo judicial na Idade Moderna. O objetivo da justiça não era criar uma igualdade diante da lei, nem chegar a um julgamento imparcial, mas, ao contrário, criar um consenso entre as partes.

${ }^{64}$ CALAFAT, Guillaume. Expertise et compétences, op. cit., p. 100-101, destaca, com base na sociologia de François Ewald, que a fronteira porosa entre explicação e julgamento é algo inerente ao procedimento conduzido por especialistas; cf. EWALD, François. L'expertise, une illusion nécessaire. In: THEYS, Jacques \& KALAORA, Bernard (org.). La Terre outragée. Les experts sont formels! Paris: Autrement, 1992, p. 203-210.

${ }^{65}$ MUNHOZ, Cláudia Simone de Freitas, op. cit., p. 124-133. Em uma cidade pequena como Porto Alegre (onde foi julgado o caso de Almeida), que contava com cerca de 12.000 habitantes em 1846 e 16.000 habitantes em 1858, os principais comerciantes, com toda a certeza, conheciam-se. Os números compreendem somente a população livre. BERUTE, Gabriel Santos. Atividades mercantis do Rio Grande de São Pedro: negócios, mercadorias e agentes mercantis (1808-1850). Tese de doutorado em História, Universidade Federal do Rio Grande do Sul, Porto Alegre, 2011, p. 44. Segundo o autor, no Livro de matrícula de negociantes de grosso trato da Real Junta do Comércio no Rio de Janeiro (1809-1850), foram listados 52 negociantes em Porto Alegre; segundo também o Almanack da Vila de Porto Alegre, n. 57, 1808, p. 141-142. Trata-se da elite comercial e não da totalidade dos comerciantes, mas foi essa elite que se associou a outros agentes econômicos pelas ligações de negócio e de crédito e ocupou os cargos dos juízes arbitrais e dos juízes de paz, entre outros cargos judiciais, administrativos e políticos.
} 
do caso de Francisco Ferreira de Almeida, Joaquim Lopes de Barros, foi, por exemplo, um dos maiores exportadores de carne na província do Rio Grande do Sul e atuava no mesmo tipo de comércio que Almeida. ${ }^{66}$ Dessa maneira, os peritos eram comerciantes que, além da reputação que tal cargo podia trazer, podiam também ter um interesse econômico próprio de atuar numa tal função. ${ }^{67}$ Ao verificar as contas de um negociante em falência, eles não somente conheciam e analisavam as contas dessa pessoa, mas também toda a rede comercial do indivíduo em questão. Isso podia trazer uma vantagem competitiva no futuro, sobretudo em cidades pequenas com um número limitado de negociantes e de capital disponível.

Porém, um segundo fator de explicação pode ser procurado em relação à própria cultura mercantil. ${ }^{68}$ Não é improvável que os parâmetros fixados para a escrituração mercantil fossem ao mesmo tempo considerados, pela maioria dos negociantes e talvez mesmo pelos juízes municipais - que não eram necessariamente letrados e podiam também fazer parte da mesma elite político-econômico local -, como altamente exigentes. Parece plausível que os atores econômicos toleraram certa negligência com os comprovantes de transações. Pois transações entre parentes e parceiros de negócios mais próximos muitas vezes não costumavam ser formalizadas por escrito. Além disso, existiam comerciantes que não sabiam escrever e, nesses casos, a escrituração mercantil podia ser feita por diversos punhos. Tudo isso explicaria o porquê de lacunas, omissões e até fraudes terem sido constatadas, mas essas irregularidades não eram levadas em conta nem no momento de elaboração do parecer nem no momento de decisão dos tribunais. Nesse sentido, as trocas comerciais são uma forma de interação social que só pode ser explicada "pelas estruturas institucionais, redes sociais e horizontes de significados dentro dos quais os atores do mercado se encontram", segundo constata o economista alemão Jens Beckert. ${ }^{69}$ Se a perícia é um contexto e uma situação,

\footnotetext{
${ }^{66}$ Ibidem, p. 82.

${ }^{67}$ CALAFAT, Guillaume. Expertises et tribunaux de commerce. Procédures et réputation à Livourne au XVIIe siècle. Hypothèses, vol. 14, n. 1, Paris, 2010, p. 145-146.

${ }^{68}$ Definimos cultura mercantil (e cultura jurídica) de uma maneira ampla como "a fábrica de valores e posições que regula a ação mercantil (jurídica)". Nota-se que essa definição inclui todo e qualquer ator econômico (ou jurídico) dentro e fora dos tribunais.

69 “(...) market action to be a form of social interaction that (...) only [can be explained] by the institutional structures, social networks, and horizons of meaning within which Market actors meet". BECKERT, Jens. The social order of markets. Theory and Society, vol. 38, n 3, Nova York, 2009, p. 247. Não é por acaso que CALAFAT, Guillaume. Expertise et compétences, op. cit., p. 103-104, recorre à chamada économie (ou sociologie) de conventions no seu artigo sobre os peritos. Pois, no conceito de économie de
} 
ou como dizem Michel Callon e Arie Rip, um lugar de debate aberto a uma multiplicidade dos atores heterogêneos, ${ }^{70}$ então o procedimento jurídico, e dentro dele a perícia, pode ser entendido como um lugar de negociação em que se encontram o mundo dos mercadores e o mundo da justiça. ${ }^{71}$

Um terceiro fator que pode explicar a reticência dos tribunais em reconhecer a escrituração mercantil como uma prova significante tem a ver com a maneira de proceder ao exame dos livros e dos comprovantes de transações. Assim, para os peritos, juízes e testemunhas parece ter sido claro que o procedimento foi altamente exposto à manipulação. Os livros comerciais, como todo tipo de escrituração mercantil, deviam ser selados no início do processo de falência. ${ }^{72} \mathrm{Na}$ prática, nas fases preliminares de conciliação e de arbitragem, esses comprovantes da falência podiam ser apropriados por sócios, amigos ou parentes. Some-se a isso o fato de poderem ser manipulados pelos próprios comerciantes falidos entre a abertura da conciliação voluntária e a arbitragem. Assim, o irmão do A. S. Levy, Salomon Levy, negociante de joias no Rio de Janeiro, declarou, durante o processo iniciado contra os supostos cúmplices da falência julgada culposa de A. S. Levy,

que ele testemunha ouvio diser a seu primo Samuel Levy, a Julio Isaac, e Jacob Schwab que os livros que forão arrecadados com os bens de A. S. Levy $\mathcal{E}$ companhia erão faltos

conventions, as convenções são recursos culturais que coordenam a ação econômica e emergem como respostas às incertezas econômicas. Elas não podem ser definidas como instituições, mas como uma hipótese inicial, da qual os atores lançam mão para acessar uma dada situação e passar à ação. As convenções servem como quadros de referência coletivamente identificados. Entretanto, elas são, ao mesmo tempo, avaliadas e reavaliadas constantemente pelos indivíduos, que decidem quando agir de acordo com certa convenção ou não. As instituições devem ser "encenadas" por atores competentes, guiados por convenções em situações reais. Elas são, portanto, "permanentemente construídas e reconstruídas através da interação e da interpretação". DIAZ-BONE, Rainer \& SALAIS, Robert. Economics of convention and the history of economies. Towards a transdisciplinary approach in economic history. Historical Social Research, vol. 36, n. 4, Köln, 2011, p. 12. Para uma visão geral, ver BOLTANSKI, Luc $\&$ THÉVENOT, Laurent. De la justification. Les économies de la grandeur. Paris: Gallimard, 1991; EYMARD-DUVERNAY, François (org.). L'économie des conventions, méthodes et resultats. 2 volumes. Paris: La Découverte, 2006.

${ }^{70}$ Devemos a referência ao texto de Callon e Rip a CALAFAT, Guillaume. Expertise et compétences, p. 103. Cf. CALLON, Michel \& RIP, Arie. Humans, non-humans: morale d'une coexistence. In: THEYS, Jacques \& KALORA, Bernard (org.). Terre outragée: lesexpertssont formels! Paris: Autrement, 1992, p. 140-156.

${ }^{71}$ CALAFAT, Guillaume. Expertises et tribunaux de commerce, op. cit., p. 153.

${ }^{72}$ BRASIL. Lei n ${ }^{\circ}$ 556, de 25 de junho de 1850, art. 809. 
e escripturados para [alegado sócio de A. S. Levy, Manoel José] Schlosmann, porque os verdadeiros tinhão sido quemados. ${ }^{73}$

No caso de Almeida, alguns dos credores se revoltaram contra o fato de que os livros dele estivessem nas mãos do seu irmão. ${ }^{74}$

Um quarto aspecto que influenciou, de ponto de vista dos juízes letrados, o processo foi o fato de as fases iniciais de conciliação e arbitragem terem sido conduzidas em um procedimento oral. As informações desses processos não chegaram até os tribunais municipais e de segunda instância, ou elas chegaram por meio de testemunhas que relatavam supostos balanços, acordos e fatos estabelecidos ao longo desses procedimentos. A comunicação entre as diferentes instâncias que atuavam nas fases do processo judicial não funcionou nem foi prevista. Assim, os documentos testemunhais que subiram para o Tribunal da Relação em favor de Francisco Ferreira de Almeida repetiam, de uma maneira concertada, o depoimento segundo o qual um dos juízes arbitrais, Joaquim José de Oliveira Castro, teria escrito uma nota - de acordo com algumas testemunhas, a lápis - referente aos valores das emissões privadas, objeto do contraditório entre Almeida e Borges. ${ }^{75}$ Esse tipo de argumentação tornou-se possível porque os documentos do Tribunal da Relação não continham qualquer informação oficial dada pelo tribunal ou juiz respectivo. O processamento da conciliação e arbitragem sucedia oralmente e não havia qualquer comunicação entre essa instância judicial e o Tribunal da Relação. Em consequência, os juízes acabavam por indagar as testemunhas se existia tal nota e em que ela consistia. Não existe evidência de que o juiz arbitral teria sido contatado pelo Tribunal para dar informações sobre o assunto.

Como em ambos os casos de Francisco de Ferreira de Almeida e de A. S. Levy não foi possível para os juízes arbitrais determinar, com base nos livros mercantis e nos bilhetes de crédito, quem foi o sócio ou o credor, as testemunhas ganharam uma importância decisiva. Tais testemunhos não

\footnotetext{
${ }^{73}$ AN. Tribunal da Relação do Rio de Janeiro, 1859. Juiz de Distrito da $1^{\text {a }}$ Vara Crime do Corte do Rio de Janeiro: Carlos Constant Chatenay e Randolpho Fischer, administradores da massa falida de A. S. Levy, apelantes, Santiago de Prate e M. J. Schlosmann, apelados, nº 837, maço 163, fl. 134v.

${ }^{74}$ AN. Tribunal da Relação do Rio de Janeiro, 1854. Sentença proveniente de agravo, extraído dos autos de agravo de interessemento de ação comercial, a favor de José Francisco de Azevedo Quintão e Francisco Lopes de Costa Moreira, agravantes, contra Francisco Ferreira de Almeida, agravado, para a cidade de Porto Alegre, $\mathrm{n}^{\circ} 2408$, cx 1605, fl. 525r.

${ }^{75}$ AN. Tribunal da Relação do Rio de Janeiro, 1854, no 2408, cx. 1605, fl. 569v, 573r-576r, 578v, $579 v-580 r, 584 v, 593 v, 594 r, 597 v$.
} 
contribuíam como fatos "forenses", no sentido de fatos realmente prováveis, mas desenvolviam uma narrativa focada na reputação e nas relações sociais dos negociantes envolvidos no conflito. Os tribunais Municipal e da Relação buscaram tomar uma decisão, multiplicando o número das testemunhas, a maioria das quais argumentava não por "ter visto", mas "saber por ter ouvido dizer a diferentes pessoas", ou "ter ouvido dizer geralmente".76

Na teoria, como destaca António Manuel Hespanha na sua obra sobre o direito comum europeu em Portugal da Idade Moderna, esse tipo de argumentação deveria ter valido menos, do ponto da vista dos tribunais, do que as testemunhas diretas ou as evidências escritas, pois:

a fé das testemunhas aferia-se pela sua dignidade, nobreza, riqueza ou outra qualidade externa; a testemunha de visu devia ser preferida a outra (Ordenações Filipinas 1,86,1); o testemunho imediato valia mais do que o mediato (de outiva, de ouvir dizer), embora este, na verdade, correspondesse ao testemunho de uma série de pessoas que sucessivamente abonavam algo que tradicionalmente era tido como verdade. ${ }^{77}$

Entretanto, na prática, baseando-se em informações de segunda mão e em fatos considerados por eles como notórios, as testemunhas falavam dos indivíduos, partes do conflito, com relação a uma "honra mercantil", constituída pela aparência e reputação (fama) do negociante. Um negociante digno de confiança e digno do crédito devia gozar de uma boa reputação, baseada na boa reputação da sua família e no comportamento moral, que era evidenciada pelo negociante pela maneira de gerir seus negócios no dia-a-dia. ${ }^{78}$ Assim, categorias construídas nas interações sociais - a honra, ${ }^{79}$ a reputação, ${ }^{80}$ a confiança ${ }^{81}$ - tinham um papel fundamental na atividade eco-

\footnotetext{
${ }^{76}$ Entre outras, ibidem, fl. 569v, 596r.

${ }^{77}$ HESPANHA, António Manuel, op. cit., p. 588. Segundo Hespanha, p. 590, na base das Ordenações Filipinas, duas testemunhas faziam prova plena nos casos em que uma lei específica não exigia mais. O Código de Comércio brasileiro de 1850 como também os regulamentos n $\mathrm{n}^{\circ} 737$ e 738 não explicitam o número de testemunhas.

${ }^{78}$ FONTAINE, Laurence. Antonio and Shylock: credit and trust in France, c. 1680-c. 1780. Economic History Review, vol. 54, n. 1, Londres, 2001, p. 39-57.

${ }^{79}$ Cf. SMAIL, John. Credit, risk and honor in eighteenth-century commerce. Journal of British Studies, vol. 44, n. 3, 2005, p. 439-456.

${ }^{80} \mathrm{Cf}$. MULDREW, Craig. The economy of obligation: the culture of credit and social relations in early modern England. Basingstoke, Nova York: Palgrave, 1998, p. 148-172; REYNARD, Pierre Claude. The language of failure: bankruptcy in eighteenth-century France. Journal of European Economic History, vol. 30, n. 2, 2001, p. 355-390.

${ }^{81}$ Cf. BOURDIEU, Pierre. The forms of capital. In: RICHARDSON, John G. (org.). Handbook of theory and research for the sociology of education. Nova York: Greenwood Press, 1986, p. 241-258; LUHMANN,
} 
nômica dos indivíduos - e simultaneamente - em todo o julgamento dessa atividade pelos tribunais. A partir da verificação de que os processos tiveram seu andamento com base em depoimentos sobre a reputação e a honra, não nos surpreende que muitos casos de falência e outros tipos de disputas econômicas foram também objeto de conflito nas páginas de jornais locais. ${ }^{82}$

Nessa lógica da "honra mercantil", as testemunhas da falência de A. S. Levy sublinharam que Levy não tinha conhecimento ou comportamento mercantil adequado ou que ele estava levando uma vida para além dos seus meios financeiros. ${ }^{83}$ As testemunhas também apontavam a vida privada de Levy como uma evidência de sua baixa credibilidade. Assim, várias testemunhas falavam ou foram perguntadas sobre o fato de que Levy, mesmo casado na França, teve uma amásia em Pelotas com a qual ele compartilhou uma moradia. ${ }^{84}$ Outras testemunham que os sobrinhos dele, Julio Isaac e Jacob Schwob, inquiridos no caso, não seriam fidedignos porque eles "não negociarão de

Niklas. Vertrauen. Ein Mechanismus der Reduktion sozialer Komplexität. 4a edição. Stuttgart: UTB, 2000. Alguns historiadores têm sublinhado que a confiança não é só estabelecida entre pessoas, mas existe também uma confiança criada pelas normas, instituições e organizações. Ver, por exemplo, GREIF, Avner. Institutions and the path to the modern economy: lessons from medieval trade. Cambridge: Cambridge University Press, 2006; GORIßEN, Stefan. Der Preis des Vertrauens. Unsicherheit, Institutionen und Rationalität im vorindustriellen Fernhandel. In: FREVERT, Ute (dir.). Vertrauen. Historische Annäherungen. Göttingen: Vandenhoeck \& Ruprecht, 2003, p. 90118; HAGGERTY, Sheryllynne. "Merely for money"? Business culture in the British Atlantic, 1750-1815. Liverpool: Liverpool University Press, 2012, p. 66-96.

${ }^{82}$ Mesmo os juízes arbitrais, juízes leigos e negociantes, podiam participar em tais discursos. SONKAJÄRVI, Hanna, op. cit., p. 183-184.

83 AN. Tribunal da Relação do Rio de Janeiro, 1859. Juiz de Distrito da $1^{\text {a }}$ Vara Crime do Corte do Rio de Janeiro; Carlos Constant Chatenay e Randolpho Fischer, administradores da massa falida de A. S. Levy, apelantes; Santiago de Prate e M. J. Schlosmann, apelados, $\mathrm{n}^{\circ}$ 837, maço 163, fl. 120v-121r, Testemunha de Eugenio Emilio Raffard: "Disse que sabe por ter ouvido dizer a diversos, entre eles a Jerson, José Levy, e outras pessoas do Rio Grande, que A. S. Levy $\mathcal{E}$ Companhia, digo A. S. Levy, membro ostensivo da firma A. S. Levy $\mathcal{E}$ Companhia, [tinha] no Rio Grande, ou Pelotas, uma casa em que morava uma sua amazia, e que não obstante ter esta casa fazia grandes despesas em um Hotel que frequentava, ignorando ele testemunha se o tratamento que tinha era superior as suas forças. Disse mais que ele testemunha sabe que o referido A. S. Levy, quando esteve ultimamente na Corte, a dizer digo na Corte a dez meses pouco mais ou menos, vendeu joias e efeitos por preços muito baixos relativamente ao preço por que as tinha comprado, ignorando se também o fez no Rio Grande (...)".

${ }^{84}$ Ibidem, fl. 119r., testemunho de Joaquim Marques Lameiras; fl. 121r., testemunho de Eugenio Emilio Raffard; fl. 176v., auto de interrogatório feito ao réu M. J. Schlosmann; fl. 180v., testemunho de Innocencio Correia Durão; fl. 198r., testemunho de Cerf Levy Olivier; fl. 204r., testemunho de Rodolpho Fischer. O fato do Levy ter sido judeu não aparece como um fator negativo nos testemunhos. 
bôa fé"85 ou "não merecem conceito algum, segundo é voz publica fundada em vários factos praticados por esses indivíduos". ${ }^{86}$ Já um acusado, cúmplice do falido, Santiago di Prati, apresentou várias cartas de recomendação escritas em seu próprio favor por diversos negociantes do Rio de Janeiro. ${ }^{87}$

\section{Conclusão}

Nosso estudo de um número de casos restritos permitiu perceber que o procedimento jurídico em relação aos casos de falência foi dominado pela palavra escrita. Os juízes de primeira e de segunda instância julgavam litígios com base nas provas escritas e testemunhos lavrados por escrivães. Nesse sistema, e mais especificamente dentro dos processos de falência, os atores locais e as ações na fase inicial do processo de falência (conciliação e arbitragem) tinham um papel decisivo. As ações e atitudes tomadas por esses atores influíam o próprio procedimento dos tribunais municipais e dos tribunais da Relação. Ao mesmo tempo, esse sistema de palavra escrita pouco se importou com a escrituração mercantil. O que prevaleceu não foi a palavra escrita dos comerciantes, mas as palavras (testemunhas) dos comerciantes escritas pelos escrivães.

Assim sendo, tentamos identificar alguns elementos que parecem poder explicar o porquê dos livros comerciais e de toda a escrituração mercantil estarem sujeitos, com base no Código de Comércio de 1850, a uma inspeção minuciosa dos peritos, sem que isso tivesse gerado consequências jurídicas na prática. Constatamos que a figura do árbitro como perito-negociante escolhido pelas partes litigantes foi completamente inserida, em termos econômicos e sociais, no próprio contexto do comércio que ele teria que inspecionar e qualificar. Nesse sentido, avaliar (e no caso dos juízes árbitros até julgar) os pares constituía uma tarefa que dificilmente permitia um posicionamento objetivo do perito. A própria cultura mercantil da época também podia ter contribuído para perceber lacunas, omissões e até fraudes com certa clemência. No fim das contas, quantos foram os comerciantes que realmente tinham seus livros de comércio e outros comprovantes de transações na ordem ideal determinada por Código de Comércio? Avaliar e julgar as evidências consistia então em um processo permanente de negociação

\footnotetext{
${ }^{85}$ Ibidem, fl. 181r., testemunho de Gabriel José Portella.

${ }^{86}$ Ibidem, fl. 180r., testemunho de Innocencio Correia Durão.

${ }^{87}$ Ibidem, fl. 161r.-163v.
} 
entre o mundo mercantil e a esfera das normas jurídicas. Além disso, os atores jurídicos, dentro e fora dos tribunais, parecem ter sido bem conscientes do fato de que a escrituração mercantil constituía uma fonte não confiável e precária, facilmente exposta à manipulação. Por fim, mais um fator que dificultou o uso das informações recolhidas em relação à escrituração mercantil nas fases iniciais dos processos de falência e do processo jurídico dos tribunais decorreu do fato de que a informação não circulou entre as diferentes escalas de justiça. O que foi negociado e constatado num processo oral na conciliação e arbitragem não chegou como informação direita pelos tribunais de primeira e segunda instâncias. Pelo contrário, se essa informação escalou na órbita dos juízes ordinários, ela foi transmitida pelas testemunhas que foram questionadas, pelas partes litigantes, sobre o que aconteceu nas fases iniciais, informações essas que foram depois lavradas pelos escrivães para ser transmitidas aos tribunais municipais e aos tribunais de Relação. Para concluir vale então sublinhar que os livros de comércio, mesmo não sendo o núcleo da constituição das provas em relação aos casos de falência (ou, talvez, exatamente por esta razão) nos permitem uma reflexão sobre o sistema jurídico do Império brasileiro e as intersecções entre a cultura mercantil e a cultura jurídica.

\section{Referências bibliográficas}

ABÁSOLO, Ezequiel. El código de comercio español de 1829 en los debates y las prácticas jurídicas del extremo sur de América. Anuario de Historia del Derecho Español, vol. 78-79, no 1, Madri, 2009, p. 447-460.

ARGOUSE, Aude. Prueba, información y papeles. Hacia una plena inclución del escribano y de sus agencias em la historia de la justicia em Hispanoamérica (Chile, siglos XVII-XVIII). Revista Historia y Justicia, vol. 8, Santiago de Chile, 2017, p. 97-137.

BASILE, Mary Elizabeth et al. (org.). Lex Mercatoria and legal pluralism: a late thirteenthcentury treatise and its afterlife. Cambridge/Mass: Ames Foundation, 1998.

BECKERT, Jens. The social order of markets. Theory and Society, vol. 38, $\mathrm{n}^{\mathrm{o}} 3$, Nova York, 2009, p. 245-269.

BENTIVOGLIO, Júlio. O império das circunstâncias: o Código Comercial e a política econômica brasileira (1840-1860). Tese de doutorado em História Econômica, Universidade de São Paulo, São Paulo, 2002.

BERUTE, Gabriel Santos. Atividades mercantis do Rio Grande de São Pedro: negócios, mercadorias e agentes mercantis (1808-1850). Tese de doutorado em História, Universidade Federal do Rio Grande do Sul, Porto Alegre, 2011.

BOLTANSKI, Luc E THÉVENOT, Laurent. De la justification. Les économies de la grandeur. Paris: Gallimard, 1991. 
BORGES, José Ferreira. Diccionario juridico-commercial. Porto: Typ. de Sebastião José Pereira, 1856 [1. ed. 1839].

BOURDIEU, Pierre. The forms of capital. In: RICHARDSON, John G. (org.). Handbook of theory and research for the sociology of education. Nova York: Greenwood Press, 1986, p. 241-258.

BRASIL. Decreto ${ }^{\circ} 737$ de 25 de novembro de 1850. Disponível em: <http://www. planalto.gov.br/CCIVIL_03/decreto/Historicos/DIM/DIM737.htm>. Acesso em: 28/04/2017.

Decreto $\mathrm{n}^{\circ} 738$ de 25 de novembro de 1850. Disponível em: <http:// www. planalto.gov.br/ccivil_03/decreto/Historicos/DIM/DIM738.htm>. Acesso em: 29/04/2017.

. Lei $\mathrm{n}^{0}$ 556, de 25 de junho de 1850, art. 10. Disponível em:<http://linker. lexml.gov.br/linker/processa?urn=urn:lex:br:federal:lei:1850-06 $=25-556$;\&urlhttp $\% 3 \mathrm{~A} \% 2 \mathrm{~F} \% 2$ Flegis.senado.gov.br\%2Flegislacao\%2FListaPublicacoes.action $\%$ 3Fid\%3D229535\%26tipoDocumento\%3DLEI\%26tipoTexto\%3DPUB\&exec $>$. Acesso em: 29/04/2017.

CALAFAT, Guillaume. Expertise et compétences. Procédures, contextes et situations de légitimation. Introduction à l'atelier doctoral "Expertise et compétences". Hypothèses, vol. 14, n. 1, Paris, 2010, p. 97-107.

Expertises et tribunaux de commerce. Procédures et réputation à Livourne au XVIIe siècle. Hypothèses, vol. 14, n. 1, Paris, 2010, p. 141-154.

CALLON, Michel $\mathcal{E}$ RIP, Arie. Humans, non-humans: morale d'une coexistence. In: THEYS, Jacques $\mathcal{E}$ KALORA, Bernard (org.). Terre outragée: les experts sont formels! Paris: Autrement, 1992, p. 140-156.

CAMPOS, Adriana Pereira \& SOUZA, Alexandre de Oliveira Bazilio de. A conciliação e os meios alternativos de solução de conflitos no Império brasileiro. Dados - Revista de Ciências Sociais, vol. 59, $\mathrm{n}^{\circ}$ 1, Rio de Janeiro, p. 271-298. Disponível em: <http://dx.doi.org/10.1590/00115258201677>. Acesso em: 29/04/2017.

CARVALHO, Darcy. Desenvolvimento e livre comércio. As ideias econômicas e sociais do visconde de Cairu. Um estudo de história do pensamento econômico brasileiro. São Paulo: Instituto de Pesquisas Econômicas, 1985.

CERUTTI, Simona. Giustizia sommaria: Pratiche e ideali di giustizia in una società di Ancien Régime (Torino, XVIII secolo). Turim: Feltrinelli, 2003.

CHAUVEAU, Adolphe. Manuel de la contrainte par corps en matière civile et commerciale. Paris: Veuve C. Béchet, 1829.

Formulaire général et complet, ou Traité pratique de procédure civile et commerciale, revu par M. Glandaz. 2 volumes. Paris: Imprimérie de Cosse, 1852.

CHAVES, Cláudia Maria das Graças. Arte dos negócios: saberes, práticas e costumes mercantis no Império luso-brasileiro. America Latina en la Historía Económica, vol. 31, n. 1, México, 2009, p. 171-193.

CORDES, Albrecht. À la recherche d'une Lex Mercatoria au Moyen Age. In: MONNET, Pierre $\mathcal{E}$ OEXLE, Otto G. (org.). Stadt und Recht im Mittelalter. Göttingen: Vandenhoeck \& Ruprecht, 2003, p. 117-132. 
DE RUYSSCHER. Dave. Designing the limits of creditworthiness. Insolvency in Antwerp bankruptcy legislation and practise (16th-17th centuries). Tijdschrift voor Rechtsgeschiedenis/Legal History Review, vol. 76, n. 3-4, Leiden, 2008, p. 307-327.

DIAZ-BONE, Rainer $\mathcal{E}$ SALAIS, Robert. Economics of convention and the history of economies. Towards a transdisciplinary approach in economic history. Historical Social Research, vol. 36, n. 4, Köln, 2011, p. 7-39.

EWALD, François. L'expertise, une illusion nécessaire. In: THEYS, Jacques \& KALAORA, Bernard (org.). La Terre outragée. Les experts sont formels! Paris: Autrement, 1992, p. 203-210.

EYMARD-DUVERNAY, François (org.). L'économie des conventions, méthodes et resultats. 2 volumes. Paris: La Découverte, 2006.

FONTAINE, Laurence. Antonio and Shylock: credit and trust in France, c. 1680-c. 1780, Economic History Review, vol. 54, n. 1, Londres, 2001, p. 39-57.

L'économie morale. Pauvreté, crédit et confiance dans l'Europe préindustrielle. Paris: Gallimard, 2008.

FRAGOSO, João Luís Ribeiro. Homens de grossa aventura: acumulação e hierarquia na praça mercantil do Rio de Janeiro (1790-1830). Rio de Janeiro: Arquivo Nacional, 1992.

GARNOT, Benoît. Histoire de la Justice. France, XVI ${ }^{e}-X X^{e}$ siècle. Paris: Gallimard, 2009.

. Justice, infrajustice, parajustice et extrajustice dans la France d'Ancien Régime.Crime, Histoire ES Sociétés/Crime, History andSocieties, vol. 4, n. 1, Paris, 2000, p. 103-120.

GORISSEN, Stefan. Der Preis des Vertrauens. Unsicherheit, Institutionen und Rationalität im vorindustriellen Fernhandel. In: FREVERT, Ute (org.). Vertrauen. Historische Annäherungen. Göttingen: Vandenhoeck \& Ruprecht, 2003, p. 90-118.

GREIF, Avner. Institutions and the path to the modern economy: lessons from medieval trade. Cambridge: Cambridge University Press, 2006.

GUIMARÃES, Carlos Gabriel. A presença inglesa nas finanças e no comércio no Brasil imperial. Os casos da Sociedade Bancária Mauá, MacGregor \& Cia. (1854-1866) e da firma inglesa Samuel Philips \& Cia. (1808-1840). São Paulo: Alameda, 2012.

GUYOT, Joseph-Nicolas. Répertoire universel et raisonné de jurisprudence civile, criminelle, canonique et bénéficiale, ouvrage de plusieurs jurisconsultes. 17 volumes. Paris: Visse, 1784-1785.

HAGGERTY, Sheryllynne. "Merely for money"? Business culture in the British Atlantic, 1750-1815. Liverpool: Liverpool University Press, 2012.

HELIE, Faustin. Traité de l'instruction criminelle ou Théorie du code d'instruction criminelle. 9 volumes. Paris: C. Ingray, 1845-1860.

HESPANHA, António Manuel. Como os juristas viam o mundo, 1550-1750. Direitos, estados, pessoas, coisas, contratos, ações e crimes. Lisboa: s. e., 2015, p. 586-587.

HILAIRE, Jean. Pratique et doctrine au début du XIXe siècle. L'oeuvre de Jean-Marie Pardessus (1772-1853). In: DEPERCHIN, Annie; DERASSE Nicolas; DUBOIS, Bruno (org.). Figures de Justice. Études en l'honneur de Jean-Pierre Royer. Lille: Centre d'Histoire Judiciare, 2004, p. 287-294.

KADENS, Emily. Order within law, variety within custom: the character of the medieval merchant law. Chicago Journal of International Law, vol. 5, n. 1, Chicago, 2004, p. 39-65. 
KESSLER, Amalia D. A revolution in commerce. The parisian merchant court and the rise of commercial society in eighteenth-century France. New Haven, Londres: Yale University Press, 2007.

KIRSCHENER, Tereza Christina. José da Silva Lisboa, visconde de Cairú: itinerarios de um brasileiro. São Paulo: Alameda, 2009.

LEVY, Maria Bárbara. A indústria do Rio de Janeiro através de suas sociedades anônimas. Rio de Janeiro: Editora UFRJ, Secretaria da Cultura do Rio de Janeiro, 1994, p. 51-57.

LOPES, José Reinaldo Lima, A formação do direito comercial brasileiro. A criação dos tribunais de Comércio do Império. Cadernos Direito GV, vol. 4, n. 6, São Paulo, 2007.

$O$ direito na história. Lições introdutórias. 4a edição. São Paulo: Atlas, 2008.

LUHMANN, Niklas. Legitimation durch Verfahren. $3^{\text {a }}$ edição. Frankfurt am Main: Suhrkamp, 1983 [1. ed. 1969].

Vertrauen. Ein Mechanismus der Reduktion sozialer Komplexität. 4a edição. Stuttgart: UTB, 2000.

MULDREW, Craig. The economy of obligation: the culture of credit and social relations in early modern England. Basingstoke, Nova York: Palgrave, 1998.

MUNHOZ, Cláudia Simone de Freitas. A Associação Comercial do Rio Grande de 1844 a 1852: interesses e atuação representativa do setor mercantil. Dissertação de mestrado, Universidade do Vale do Rio dos Sinos, São Leopoldo, 2003.

NEVES, Edson Alvisi. Magistrados e negociantes na Corte do Império do Brasil: O Tribunal do Comércio. Rio de Janeiro: Jurídica do Rio de Janeiro, Faperj, 2008.

PAQUETTE, Gabriel. José da Silva Lisboa and the vissitudes of enlightened reform in Brazil, 1798-1824. In: PAQUETTE, Gabriel (org.). Enlightened reform in southern Europe and its Atlantic colonies, c. 1750-1830. Londres: Farnham, 2009, p. 361-388.

PARDESSUS, Jean-Marie. Élémens de jurisprudence commerciale. Paris: Durand, 1811. Cours de droit comercial. 4 volumes. Paris: Librairie Garnery, 1814-1816.

PETIT, Carlos. Historia del derecho mercantil. Madri: Marcial Pons, 2016.

REYNARD, Pierre Claude. The language of failure: bankruptcy in eighteenth-century France. Journal of European Economic History, vol. 30, n. 2, 2001, p. 355-390.

RIDINGS, Eugene. Business interest groups in nineteenth-century Brazil. Cambridge: Cambridge University Press, 1994.

SMAIL, John. Credit, risk and honor in eighteenth-century commerce. Journal of British Studies, vol. 44, n. 3, 2005, p. 439-456.

SONKAJÄRVI, Hanna. A aplicação do Código Comercial brasileiro entre 1850 e 1860 : análise das evidências de um caso de falência culposa. Tempo. Revista do Departamento de História da UFF, vol. 21, n. 37, Niterói, 2015, p. 170-186. Disponível em: <http:// dx.doi.org/10.1590/tem-1980-542x2015v213704>. Acesso em: 29/04/2017.

TOUBEAU, Jean. Les institutes du droit consulaire, ou la jurisprudence des marchands. Paris: J. Guignard, 1682.

Recebido : 23/09/2016 - Aprovado : 19/06/2017 